\title{
Szemfelszíni laphám-neoplasia
}

\author{
Tóth Gábor dr. ${ }^{1}$ - Sándor Gábor László dr. ${ }^{1}$ \\ Gyenes Andrea dr. ${ }^{1}$. Tóth Jeannette dr. ${ }^{2}$ - Berthold Seitz dr. ${ }^{3}$ \\ Nagy Zoltán Zsolt dr. ${ }^{1}$ - Szentmáry Nóra dr. ${ }^{1,3}$
}

\author{
Semmelweis Egyetem, Általános Orvostudományi Kar, ${ }^{1}$ Szemészeti Klinika, ${ }^{2}$ II. Patológiai Intézet, Budapest \\ ${ }^{3}$ Klinik für Augenheilkunde, Universitätsklinikum des Saarlandes, UKS, Homburg/Saar, Deutschland
}

\begin{abstract}
Jelen összefoglalóban a szemfelszíni laphám-neoplasiáról való ismereteket összegzik a szerzők, beleértve ezen daganattípus epidemiológiáját, etiológiáját, patológiáját, klinikai megjelenését és kezelését. A conjunctivalis intraepithelialis neoplasiával és az invazív laphámrákkal kapcsolatos közleményeket tekintették át a szerzôk néhány saját eset bemutatásával, amelyek alapján olyan alapvető írást szeretnének közölni, amely részletesen taglalja és bemutatja jelenlegi ismereteinket a szemfelszíni laphám-neoplasiáról. A szemfelszíni laphám-neoplasia a leggyakoribb szemfelszíni malignus tumor, illetve a choroidealis melanoma malignumot és a lymphomát követően a harmadik leggyakoribb okuláris malignoma. Alacsony malignitási potenciálja ellenére előrehaladott stádiumban jelentős látásromláshoz vezethet, ső́t akár a szemgolyó eltávolításának szükségessége mellett távoli metasztázis kialakulásakor az életet is veszélyeztetheti. Gyakori recidívaképződés miatt kezelésében elengedhetetlen az intra- és posztoperatív adjuváns kezelési módok ismerete és alkalmazása, valamint a rendszeres kontrollvizsgálat. A szemfelszíni laphám-neoplasia felismerése és adekvát kezelése elengedhetetlen ezen tumortípus progressziójának elkerülésében és a recidíva kialakulásának megelőzésében.
\end{abstract}

Orv Hetil. 2017; 158(51): 2011-2022.

Kulcsszavak: conjunctivalis intraepithelialis neoplasia, laphámrák, szemfelszíni laphám-neoplasia

\section{Ocular surface squamous neoplasia}

To summarize actual knowledge on epidemiology, etiology, pathology, clinical apparence and treatment of ocular surface squamous neoplasias. We summarize up-to-date literature on conjunctival intraepithelial neoplasia and invasive squamous cell carcinoma and present some own cases. Ocular surface squamous neoplasia is the most common malignant ocular surface tumor and the third most common ocular malignancy following malignant melanoma and lymphoma. In spite of its low malignant potential, in advanced stages it may reduce visual acuity significantly or even the eye globe has to be removed. In case of metastasis it may also be life-threatening. As local recurrences of ocular surface squamous neoplasias may occur, knowledge of intra- and postoperative adjuvant treatment options are indispensable and regular control examinations are necessary. Identification and adequate treatment of ocular surface squamous neoplasias are necessary in order to avoid its progression and to prevent recurrences.

Keywords: conjunctival intraepithelial neoplasia, squamous cell carcinoma, ocular surface squamous neoplasia

Tóth G, Sándor GL, Gyenes A, Tóth J, Seitz B, Nagy ZZs, Szentmáry N. [Ocular surface squamous neoplasia]. Orv Hetil. 2017; 158(51): 2011-2022.

(Beérkezett: 2017. szeptember 20.; elfogadva: 2017. október 4.)

\section{Rövidítések}

5-FU = 5-fluorouracil; AJCC $=$ American Joint Committee on Cancer; BCVA $=$ (best corrected visual acuity) legjobb korrigált látóélesség; $\mathrm{CIN}=$ (conjunctival intraepithelial neoplasia $)$ conjunctivalis intraepithelialis neoplasia; HPV = humán papil- lomavírus; IFN- $\alpha-2 b=$ interferon-alfa- $2 b ; M M C=$ mitomycin $\mathrm{C} ;$ OSSN = (ocular surface squamous neoplasia) szemfelszíni laphám-neoplasia; SCC = (squamous cell carcinoma) laphámrák; UV-B = ultraibolya $\mathrm{B} ; \mathrm{VEGF}=$ (vascular endothelial growth factor) vascularis endothelialis növekedési faktor 
Bár a szemfelszíni laphám-neoplasia (ocular surface squamous neoplasia - OSSN) megjelenése ritka, de malignitási potenciálja miatt fontos a kórkép felismerése, differenciálása és megfelelő kezelése. Az OSSN a leggyakrabban előforduló szemfelszíni malignus neoplasia, illetve a choroideamelanoma és az okuláris lymphoma után a harmadik leggyakoribb okuláris tumor [1]. Incidenciája világszerte nói-férfi bontásban $0,08-0,18$ / 100 000-re tehető. Az OSSN érintheti külön-külön a kötőhártyát és a szaruhártyát is, de többnyire a conjunctiva hámjából indul ki, majd a limbuson keresztül terjed a corneára [2].

A kórkép nómenklatúrája napjainkban sem egységes. Elöször „epithelioma” néven von Graefe írta le 1860ban. Lugossy Gyula, az Országos Reumatológiai és Fürdőügyi Intézet Szemészeti Osztályának osztályvezető fóorvosa 1956-ban a limbus „praecancerosus epitheliomájának” nevezte [3]. A „conjunctivalis intraepithelialis neoplasia" (CIN) elnevezést Pizarello és Jakobiec vezette be 1978-ban, amellyel akkor az enyhe, közepes és a súlyos dysplasiát nevezték meg. Waring ugyanezen kórképet 1984-ben „cornealis intraepithelialis neoplasia” néven említette. Napora 1990-ben kiegészítette a CIN fogalmát és addigi spektrumát (dysplasia, carcinoma in situ) az invazív laphámrákkal (squamous cell carcinoma - SCC). A ma leginkább elterjedt „szemfelszíni laphámneoplasia" terminust Lee és Hirst vezette be a szemészetbe 1995-ben, ami felöleli a dysplasiától az invazív SCCig a teljes spektrumot [4].

\section{Epidemiológia}

Egy 1961 és 1966 között végzett tanulmány szerint az OSSN átlagos incidenciája 0,13/100 000 fó volt Ugandában [5], míg egy 25 évvel frissebb közlemény szerint az OSSN incidenciáját 1992-ben 0,13/100 000 före becsülték Ausztráliában [1] és 0,3/1 000000 före az Amerikai Egyesült Államokban [6]. A kórkép az erősebb napsugárzás miatt az Egyenlítő környékén a leggyakoribb, incidenciája pedig északi irányba haladva 10 szélességi fokonként 49\%-kal csökken [7]. Leggyakrabban felnőtt férfiakban fordul elő, aminek hátterében valószínúleg az áll, hogy a férfiak gyakrabban végeznek szabadtéri munkát. Az ezredfordulón a regionális és nemi különbségek a korábbi közlemények eredményeihez képest növekedést mutattak. A nói-férfi incidenciát ekkor Európában 0,01-0,05/100 000-re, Észak-Amerikában 0,00-0,08/ 100 000-re, míg Dél- és Közép-Amerikában 0,28-0,41/ 100 000-re, Afrikában pedig 1,18-1,38/100 000-re becsülték [8]. A fiatalabb korban megjelenő OSSN többnyire xeroderma pigmentosumos pácienseknél jelenik meg [9].

\section{Etiológia}

$\mathrm{Az}$ OSSN kialakulásában szerepet játszó legfontosabb környezeti tényezőnek a Nap ultraibolya B (UV-B) -su- gárzását tartják [1]. Fokozatosan távolodva az Egyenlítőtől, fokozatosan csökken az UV-B-sugárzás és azzal együtt az OSSN előfordulása. Ennek feltehető oka, hogy az UV-B-sugárzás károsítja az epithelsejtek DNS-ét, és a DNS-javításban kialakult hiba vagy késés szomatikus mutációkhoz és tumorsejtek kialakulásához vezethet [10].

A humán papillomavirus (HPV) jelentőségének megítélése nem egységes az OSSN etiológiájában. Jól ismert a HPV 16 és 18 méhnyakrák kialakulásában játszott szerepe. A cervicalis intraepithelialis neoplasiák körülbelül $80 \%$-ában és a cervicalis laphámrákok mintegy $90 \%$-ában kimutatható a HPV 16 és 18 szerotípusa [11]. A méhnyaknál lévő hám átmenete és a conjunctiva-cornea közötti átmenet hasonlósága miatt a HPV OSSN kialakulásában játszott szerepe intenzíven tanulmányozott terület. Számos tanulmányban írták le a HPV OSSN kialakulásában játszott szerepét $[12,13]$, azonban közlésre került olyan tanulmány is, amely nem tudta kimutatni a HPV szignifikáns szerepét az OSSN kialakulásában [14]. Más esetekben mindkét szemben sikerült kimutatni a HPV-t, a tumor azonban csak egyoldali volt [13]. Jelentek meg közlemények olyan esetekről is, ahol genitálisan mutatták ki a HPV-t, a conjunctiva azonban ép volt. Emellett olyan eredmények is fellelhetőek a szakirodalomban, ahol alacsony volt az OSSN-es páciensek HPV-fertőzöttsége. Minden valószínúség szerint önmagában a HPV hatására nem alakul ki OSSN, de magas UV-B-sugárzás esetén vagy más egyéb kofaktorral együtt már lényeges etiológiai tényező lehet [2].

Az OSSN incidenciája jelentősen megnőtt az AIDS felbukkanása óta. Ugandában 1988 és 1992 között az OSSN incidenciája hétszeresére növekedett és a betegek 75\%-a HIV-szeropozitivitást mutatott [15]. Newton szerint a HIV-szeropozitivitás tízszeres rizikót jelent az OSSN kialakulását tekintve [16]. Egy Malawiban végzett tanulmány szerint az OSSN-es betegek 78\%-a HIV-pozitív volt [17]. Karp közleményében kilenc 50 év alatti floridai OSSN-es páciensről ír, akik közül hat HIV-fertőzött volt [18]. Egy másik tanulmány szerint a HIV-szeropozitív OSSN-esek átlagosan 17 évvel fiatalabbak, mint a szeronegatívak. Ezenkívül a HIV-fertőzött pácienseknél a tumor agresszívabb viselkedésű és gyorsabban nő, mint HIV-negatív betegeknél. Ezért javasolt minden 50 év alatti OSSN-es beteg esetében a HIV-teszt elvégzése [18].

A kevésbé jelentős rizikófaktorok közé tartozik a dohányzás, a petróleumnak való kitettség és az okuláris pigmentáció [10]. Guex-Crosier szerint a kontaktlencse-viselésnek az általa okozott mechanikai ártalmakon keresztül lehet szerepe az OSSN kialakulásában [16].

\section{Klinikai jellemzők}

A páciensek legtöbbször irritációérzés, szemvörösség, idegentest-érzés vagy szemfelszínen növekvő terime miatt keresik fel a szemészeti rendelést, azonban az esetek 
30\%-a teljesen tünetmentes. Kiterjedt OSSN esetén, ha az elváltozás astigmiát okoz vagy eléri az optikai zónát, látásromlás is előfordulhat.

A legtöbb conjunctivalis OSSN az interpalpebralis régióban megjelenő, enyhén kiemelkedő, jellegzetes érgomolyagokat tartalmazó és gyöngyházszürke megjelenésû. A tumorszél egyes esetekben jól, máskor kevésbé jól látható. Az esetek nagy részében a kötőhártyából indul ki, majd pedig a limbuson át terjed a szaruhártyára, de esetenként primeren a cornealis hám területében is megjelenhet. Klinikai megjelenése legtöbbször „zselatinszerü", de lehet leukoplakiás és papillomatosus is. Az OSSN nodularis típusa gyakrabban fordul elő, gyorsabban nő és jól látható szélei vannak, míg a diffúz típust csak ritkábban láthatjuk, kezdetben nehezebben felismerhető, elmosott szélü, lassan progrediáló és a krónikus kötőhártya-gyulladástól csak nehezen különböztethető meg [2]. A CIN és az SCC makroszkópos elkülönítése nem lehetséges, azonban a subconjunctivalis részekhez való kötöttség és immobilitás malignitásra utaló jel [4]. A cornealis laesio általában enyhén elemelkedő, opálos szürke és jól demarkált, felszíne pedig fluoreszcein festékkel pontszerü festődést mutat. A bengálvörös festék ábrázolja a kóros hámsejtekkel fedett területeket, így segítségünkre lehet a tumorszélek meghatározásában [19].

A szemészeti vizsgálat során fontos a szemhéjak kifordítása, illetve a tarsalis kötőhártya és a fornix vizsgálata is, mert az OSSN esetenként ezekről a területekről indul ki. Habár az intraokuláris terjedés extrém ritka (2-8\%), az elülső csarnok érintettségének kizárására érdemes gonioszkópiás vizsgálatot végezni [20]. Intraokuláris terjedés esetén az OSSN infiltrálhatja az elülső csarnokot, a Schlemm-csatornát, az irist és a trabecularis hálózatot, így elülső uveitist és szekunder glaucomát okozhat. Orbitalis érintettség rendkívül ritka [10].

A fentiek mellett lényeges a cervicalis, submandibularis és praeauricularis nyirokcsomók megtapintása is, az esetleges regionális áttétek felismerése céljából [21].

A távoli áttét irodalmi ritkaság, az agyban, tüdőben és a csontban alakulhat ki [22]. Napjainkig kilenc olyan eset lelhető fel a nemzetközi szakirodalomban, ahol a halál közvetlen okaként az OSSN-t jelölték meg, de a leírások ezekben az esetekben is többnyire hiányosak. Differenciáldiagnosztikai szempontból elkülönítendőek a conjunctivalis/cornealis pannus, pinguecula, pterygium, papilloma, benignus intraepithelialis dyskeratosis, cornealis epithelium keratinizációja és a conjunctivalis melanoma malignum [4].

\section{Hisztopatológia}

Az OSSN-ben a hám kiszélesedik, szerkezetének szabályos rétegzettsége megszünik, az érintett rétegekben pedig sejtatípia látható. Emellett mitotikus sejtosztódás a bazális réteg fölött is megfigyelhető. Sejtatípia esetén a bazális sejtek megnagyobbodnak, megnyúlnak és bazofilebbé válnak. A bazális sejtek lapos sejtekké való fizioló- giás érése hiányzik vagy csökkent. A mag/plazma arány a mag javára eltolódott és a hámrétegben helyenként dyskeratosisok figyelhetőek meg [23].

Az OSSN szövettani súlyosságától függően a következő spektrumot öleli fel:

I. CIN: Praecancerosus állapotnak tekinthető. I/I Dysplasia:

a) Enyhe: Az atípiás sejtek a hám bazális egyharmadában vannak csak jelen.

b) Középsúlyos: Az atípiás sejtek a hám bazális kétharmadára lokalizálódnak.

c) Súlyos: Az atípia a hámréteg teljes vastagságában megtalálható, a dysplasticus sejtek a felsó harmadban is jelen vannak [24].

I/2 Carcinoma in situ (CIS): A súlyos dysplasiában $(\mathrm{I} / \mathrm{l} / \mathrm{c})$ még némi kiérés megfigyelhetố a bazális rétegek irányából a felszín felé, CIS-ben ez már nincsen jelen [4].

II. Invazív SCC: A pleomorph, atipikus daganatsejtek áttörik a bazális membránt, azaz a kötőhártya esetében a daganatsejtek megjelennek a substantia propriában, a szaruhártyánál pedig áttörik a Bowman-lamellát és megjelennek a strómában [25].

A CIN átlagosan öt-kilenc évvel fiatalabb populációban fordul elö, mint az SCC, ami arra utal, hogy a praecancerosus CIN SCC-vé alakulhat. Az idő múlásával ugyanígy az enyhe dysplasia középsúlyos, majd súlyos dysplasiává, illetve SCC irányába progrediálhat.

Az invazív SCC lehet jól differenciált és rosszul differenciált. Jól differenciált tumor esetén a hámsejtek könynyedén felismerhetőek, nagy sejtekből állnak és sejtmagvaik hiperkromatikusak. Emellett a hámrétegen belül helyenként hyperkeratosis és dyskeratosis figyelhető meg.

Rosszul differenciált SCC (1. ábra) nehezen különböztethető meg más malignus tumoroktól (például se-

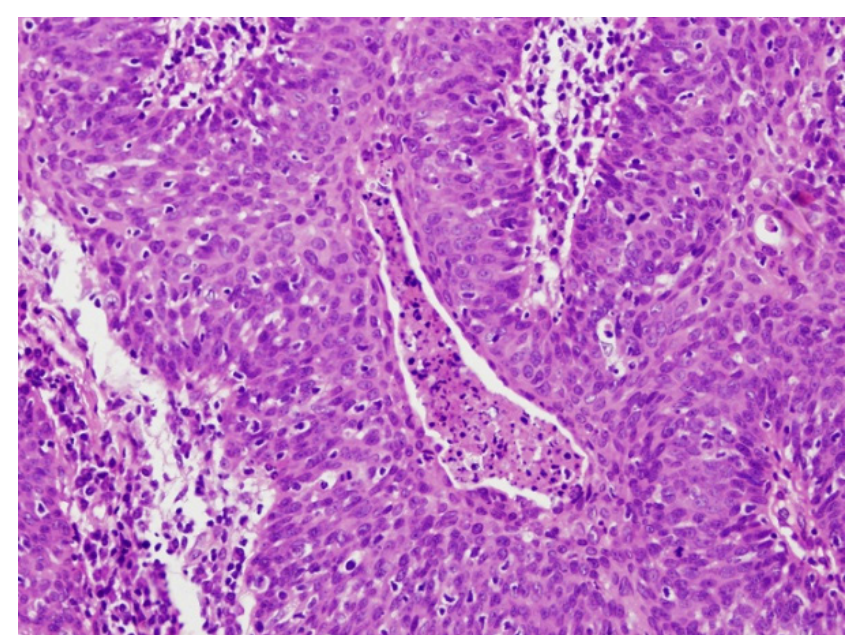

1. ábra $\mid$ Differenciálatlan invazív laphámrák szövettani képe (hematoxilin-eozin festés, 200-szoros nagyítás). A sejtekben a sejtmag/ citoplazma arány a sejtmag javára eltolódott. A hám teljes vastagságában mitózisok láthatóak 
baceus carcinomától). Hisztológiai vizsgálat során a hámsejtek között orsósejteket és mucoepidermoid sejteket figyelhetünk meg, és a hámsejtek nehezen felismerhetőek. A rosszul differenciált SCC ritka, de igen agreszszív viselkedésű tumor [2].

\section{Citológia}

A citológia kiegészítő vizsgálati módszer lehet az OSSN differenciáldiagnosztikájában és követésében.

Exfoliatív citológia során mintavevő kefével vagy impressziós citológia során cellulózalapú filterpapír segítségével a felszínes rétegekben lévő sejteket vizsgálhatjuk.

CIN esetén a mintavétel során megnagyobbodott, irreguláris, hiperkromatikus dysplasticus sejteket láthatunk, esetenként keratinizációval és syntitialis csoportosulásban [4]. SCC esetén azonban a dysplasticus sejtek mellett gyulladásos sejteket és bizarr alakú malignus sejteket is láthatunk (ebihal alakú sejtek, orsósejtek) [26].

A citológiai vizsgálatnak szerepe lehet a mútét előtti differenciáldiagnosztikában, illetve esetenként a konzervatív kezelés hatásosságának nyomon követésében és az esetleges recidívák felismerésében. A módszer hátránya, hogy csak a felszíni sejteket vizsgálhatjuk, amelyekből nem mindig megítélhető, hogy invazív SCC-vel állunk-e szemben. A citológiai vizsgálat eredményességének nélkülözhetetlen feltétele a tapasztalt citológus szakember, de a citológiai vizsgálatok még ilyenkor is csak a később szövettani vizsgálattal igazolt esetek $77 \%$-ában pozitívak [27].

\section{Klinikai osztályozás}

$\mathrm{Az}$ American Joint Committee on Cancer (AJCC) OSSN-klasszifikációja a TNM-osztályozást használja [28], amelyben a T betű a primer tumor méretét és kiterjedését, az $\mathrm{N}$ betû a regionális nyirokcsomó érintettségét, az $\mathrm{M}$ betû́ pedig a távoli áttétre vonatkozó információkat jelöli (1. táblázat).

\section{Kezelés}

A kezelés alapvetően három célt szolgál: a tumorszövet teljes eltávolítását, a recidíva kialakulásának elkerülését és a szemfelszín integritásának helyreállítását. A kimetszett terület szélének szövettani vizsgálata és az épben történő kimetszés alapvető fontosságú az eltávolítás sikeressége és a recidíva megelőzése szempontjából. Az OSSN kezelése tekintetében nincsenek irányelvek, egységes kezelésükhöz az evidenciákon alapuló adatok hiányoznak. Ennek oka, hogy a rendelkezésre álló tanulmányok nehezen összehasonlíthatóak az alacsony esetszámok, az esetek eltérő kórszövettani súlyossága és kiterjedése, illetve az eltérő kezelési módok miatt.

Az OSSN kezelése során alkalmazhatunk sebészi eltávolítást, amelyet intraoperatív adjuváns kezeléssel egé-
1. táblázat | A „szemfelszíni laphám-neoplasia” TNM-osztályozása (American Joint Committee on Cancer OSSN-klasszifikációja) [28]

\begin{tabular}{ll}
\hline Primer tumor $(\mathrm{T})$ & Definíció \\
\hline TX & Nem megállapítható \\
T0 & Nincs tumor \\
Tis & Dysplasia/carcinoma in situ \\
T1 & A legnagyobb átmérő $\leq 5 \mathrm{~mm}$ \\
T2 & A legnagyobb átmérő $>5 \mathrm{~mm}$ \\
T3 & A tumor érinti a környező \\
T4 & szöveteket (kivéve orbita) \\
\hline Regionális nyirokcsomó-érintettség & A tumor infiltrálja az orbitalis \\
kötőszövetet
\end{tabular}

szíthetünk ki. Emellett preoperatív gyógyszeres adjuváns kezelés alkalmazható a tumorszövet méretének csökkentésére, illetve posztoperatív gyógyszeres adjuváns kezelés vagy brachytherapia a recidíva megelőzésére. Az elmúlt években mintegy paradigmaváltásként az OSSN kezelésében a tisztán konzervatív kezelés is megjelent.

Ezen kezelési módok eredményességét foglaljuk össze a következókben.

\section{Operatín kezelés}

\section{Sebészi kimetszés}

Az OSSN tradicionális kezelése a tumorszövet sebészi eltávolítása. Javasolt a mútét retrobulbaris érzéstelenítésben való elvégzése, hiszen a subconjunctivalis érzéstelenítés a tumor szóródását és a kötőhártya szerkezetének megváltozását idézheti eló. Különösen lényeges a megfelelő biztonsági széllel való kimetszés, amelynek vonatkozásában a különböző közlemények 1-4 mm közötti értékeket javasolnak [29-31]. Javasolt a teljes tumorszövet egy ülésben való eltávolítása. Amennyiben az operált kötőhártyaszél nem látszik tumorsejtmentesnek, akkor a nem eltávolított conjunctiva széléből szövettani vizsgálat céljából biopszia vétele javasolt. A mútét során először az érintett szaruhártya-epitheliumot és a tumorszövet környezetében lévő $2 \mathrm{~mm}$-es sávban lévő hámréteget távolítjuk el. Amennyiben a tumor a Bowman-lamellát áttörte, superficialis keratectomiát is végzünk. Következő lépésben a tumorszövet érintése nélkül lamellaris scleroconjunctivectomiát végzünk. Ollóval a megfelelő biztonsági széllel körbepreparáljuk a neoplasticus elváltozást, eltávolítva így az erre a területre eső kötőhártya- és 
Tenon-tok-részeket. Ezt követően, tartva a szükséges biztonsági széleket, $0,2 \mathrm{~mm}$ mélyen sclerectomiát végzünk, ügyelve arra, hogy a limbalis régióban a Bowmanlamellát ne sértsük meg. Az esetlegesen megmaradt tumorsejtek devitalizálása céljából a scleralis alapon etanolos átdörzsölés végezhető [32]. Végül a mútét végén zárjuk a conjunctivasebet.

Egyes szerzók lamellaris sclerectomiát csak abban az esetben végeznek, amennyiben az ínhártya makroszkóposan involváltnak látszik $[30,33]$.

Kiterjedt kötőhártyahiány esetén kötőhártya-plasztikát vagy amnionmembrán-átültetést végezhetünk (az amnionmembránt conjunctivalis graftként alkalmazzuk). Sebészi eltávolítás során nagyon lényeges az eltávolított szövetdarabon az egyes irányok megjelölése, hogy ha a kimetszés valamelyik oldalon nem az épben történt, ott a tumorszövet teljes eltávolításának céljából reoperációt végezhessünk.

Mivel azonban az OSSN-recidíva kialakulásának valószínüsége, még az épben történt kimetszés esetén is 22$56 \%$, javasolt a sebészi eltávolítás egyéb intra- vagy posztoperatív kezeléssel való kombinálása, csökkentve ezzel a tumor kiújulásának esélyét (lásd később) [34].

\section{Enucleatio, exenteratio}

Intraokuláris terjedés esetén enucleatio, intraorbitalis terjedés esetén pedig exenteratio elvégzése javasolt [10].

\section{Intraoperatí adjuváns kezelés}

\section{Cryotherapia}

A cryotherapia tradicionálisan a leggyakrabban alkalmazott adjuváns kezelés, amelynek során „double freezethaw" technikával megfagyasztjuk a bent maradt kötőhártyaszéleket a következők szerint: Az eljárás során a cryovéget a conjunctivalis szél bulbaris oldalához helyezzük, elemelve azt a sclerától, így elkerülve a sclera vagy az irisgyök fagyasztását. Egy-egy fagyasztási epizód körülbelül 10 másodpercig tart. Ezt követően megvárjuk, míg felenged az előbb megfagyasztott kötőhártyarész, majd pedig ismételten fagyasztjuk ugyanazt a conjunctivaterületet. Ezután $3 \mathrm{~mm}$-rel odébb helyezzük a cryovéget és az előbbi eljárást megismételjük. Ilyen módon körbehaladva kezeljük a teljes kötőhártyaszélt [32]. Sarici a sclera fagyasztását is javasolja, amennyiben azt infiltrálja a tumor [30]. Tunc sebészi eltávolítást és „double freezethaw" cryotherapiát végzett 60 esetben, és átlagosan 56 hónap alatt a pácensek 4,5-5,3\%-ánál lépett fel recidíva [33].

\section{Mitomycin C (MMC)}

Az MMC a Streptomyces caespitosus által termelt antimetabolit hatású vegyület, amely a DNS-szintézist gátolja és így az OSSN recidíváját csökkenti, illetve a mútétet követő hegesedést mérsékli. Sarici $3 \mathrm{~mm}$-es biztonsági szegéllyel történő kimetszést követően cryotherapiát végzett, majd pedig három percre $0,02 \%$-os $\mathrm{MMC}$-vel átitatott szivacsot helyezett az eltávolított tumorszövet alatti sclerára és a subconjunctivalis területre. Negyvenkilenc hónapos átlagos utánkövetési időt követően a 28 kezelt páciens egyikénél sem talált kiújulásra utaló jelet [30]. Khokhar 2-3 mm-es biztonsági szegéllyel történő kimetszést és fagyasztást követően öt percig 0,02\%-os MMC-kezelést alkalmazott az érintett területen, a kezelést követő egy évben pedig öt páciensből egynél sem talált recidívát [35]. Siganos sebészi excisiót követően végzett öt percen keresztül 0,02\%-os MMC-kezelést, majd 16 hónapos átlagos utánkövetésnél hét páciens közül egynél lépett fel recidíva [36].

MMC intraoperatív alkalmazása esetén, a szivacs eltávolítását követően, a szövődmények elkerülése érdekében (lokális toxicitás, tumorindukáló hatás) fiziológiás sóoldattal bő átmosást kell végezni.

\section{Amnionmembrán-átültetés, kötőhártyafedés}

Nagy kiterjedésú tumor eltávolítását követően szemfelszín-rekonstrukció céljából amnionmembránt conjunctivalis graftként alkalmazva (szövetpótlás) kötóhártyaplasztikát, illetve ritka, előrehaladott esetekben a szaruhártya kötőhártyafedését végezhetjük [37].

\section{Pre-és posztoperatín adjuváns kezelés}

Az adjuváns kezelések preoperatív rendelésének célja a tumorszövet kiterjedésének sebészi etávolítást megelőző kisebbítése. A posztoperatív adjuváns kezelések célja az esetlegesen nem az épben történt sebészeti eltávolítást követően a maradék tumorszövet rezolúciója és a recidíva megelőzése.

\section{Vascularis endothelialis növekedési faktort gátló sze- rek (anti-VEGF)}

A VEGF-ek fontosak a vér- és nyirokerek kialakulásának szabályozásában. Az anti-VEGF-vegyületek használata elterjedt különböző neoplasiák kezelésében, mivel csökkenteni tudják a tumor méretét és erezettségét is. Ismert, hogy az anti-VEGF-vegyületek gátolják a cornealis vérés nyirokerek kialakulását [38]. Faramarzi 10 OSSN-es szemet kezelt két alkalommal 2,5 mg bevacizumab subconjunctivalis adásával (két hét szünet a kezelések között), a sebészi eltávolítást megelőzően. Az első injekciót követően $25 \%$, a második injekciót követően $42 \%$ redukciót tapasztalt a tumor conjunctivalis kiterjedésében. Finger öt SCC-s szemet kezelt átlagosan 19 hónapon át kettő-négy hetente subconjunctivalis ranibizumabinjekcióval (0,5 mg alkalmanként), amelynek hatására három páciens esetében teljes rezolúciót ért el. Két páciensnél pedig a kezdeti javulás ellenére a tumorszövet sebészi eltávolítása vált később szükségessé. Özcan 10 OSSN-es szemet naponta $4 \times 125 \mathrm{mg} / \mathrm{ml}$ bevacizumab szemcseppel kezelt, és átlagosan 7,8 hét után klinikailag gyógyulás volt látható, hat hónapos utánkövetés során pedig recidívát nem észlelt. A lokális kezelést a betegek mindaddig folytatták, amíg a tumor mérete csökkent. Asena hat OSSN- 
es szemet kezelt nyolc héten át naponta $4 \times 15 \mathrm{mg} / \mathrm{ml}$ bevacizumab szemcseppel, amelynek hatására a második hónapra 68\%-os redukciót ért el, két esetben pedig impressziós citológiával igazolt teljes rezolúciót [39].

\section{MMC}

Az MMC hosszú távú használata során enyhébb esetekben kötőhártya-hyperaemia, keratitis superficialis punctata, de súlyosabb esetekben akár scleralis beolvadás, steril keratolysis, limbalis őssejt-elégtelenség vagy szaruhártya-erózió is kialakulhat, ezért adagolása a mellékhatások kialakulásának megelőzése céljából ciklusokban javasolt. Lokális MMC-kezelés során általában egy ciklus MMC-használatot egy hét kezelésmentes időszak követ. A kezelés megindítása előtt meg kell várni a szemfelszín teljes reepithelisatióját. Gupta sebészi excisiót és cryotherapiát követeőn 73 páciensnél alkalmazott a mútétet követően négy-hat hét alatt két-három ciklusban, naponta $4 \times 1$ 0,04\%-os MMC szemcseppet, amivel 100\%ban ért el teljes rezolúciót és 56 hónapos átlagos utánkövetésnél $0 \%$-ban talált recidívát [40]. Kashkouli sebészi eltávolítást és fagyasztást követően szintén két-három ciklusban adta a 0,04\%-os MMC szemcseppet, így 17 páciensből egynél alakult ki recidíva kilenc hónapot követően, de az MMC-kezelést megismételve újbóli recidíva nem alakult ki. Babrami és mtsai az előbbiekkel megegyező kezeléssel, 57 hónapos átlagos utánkövetéssel 64 betegnél egyetlen esetben sem találtak tumorrecidívára utaló jelet. MMC adása kontraindikált Sjögren-szindrómában, rosaceában és atópiás kórképekben [41].

\section{5-fluorouracil (5-FU)}

Az 5-FU antimetabolit hatású pirimidinanalóg vegyület, amely a DNS-szintézist gátolja. Mellékhatásspektruma jóval enyhébb, mint az MMC-nek, azonban conjunctivalis hyperaemiát vagy keratitis superficialis punctatát az 5-FU alkalmazása is okozhat. A Liverpooli Szemészeti Onkológiai Centrum ajánlása szerint az OSSN mütéti eltávolítását követően és a teljes hámosodás lezajlása után négyciklusnyi 1\%-os 5-FU adása javasolt, naponta $4 \times 1$ szemcsepp formájában. 5-FU esetén egy ciklus egy hétig tartó cseppentést, majd pedig három hétig tartó szünetet jelent [29]. Bahrami tanulmányában 89 páciens kapott két héten át $4 \times 1$ 1\%-os 5-FU-szemcseppet az OSSN sebészi eltávolítását és cryopexiát követően. Harminchárom hónapos átlagos utánkövetést követően egyetlen páciensnél alakult ki recidíva [41].

\section{Interferon-alfa-2b (IFN- $\alpha$-2b)}

$\mathrm{Az}$ interferonok (IFN) a természetben is előforduló fehérjék, amelyeknek fontos szerepük van az endogén és exogén ártalmakkal szembeni immunvédekezésben. Az IFN-ek használata elterjedt a vesesejtes carcinoma, a melanoma malignum, a méhnyakrák, a fej-nyaki tumorok, a medullaris pajzsmirigy-carcinoma, a myeloma multiplex, a krónikus myeloid leukaemia, a hepatitis-B és a hepatitis-C kezelésében [42].
Az IFN- $\alpha$-2b szemcseppként és subconjunctivalis injekció formájában adható az OSSN kezelése során. A subconjunctivalis (perilaesionalis) injekció szöveti penetrációja lényegesen jobb a szemcseppénél, illetve a páciens elégtelen együttmúködése esetén is adható, azonban alkalmazása során jelentősebbek a szisztémás mellékhatások is (láz, megfázás, rossz közérzet) [43].

Shields 81 szem esetében használt naponta $4 \times 1$ $1 \mathrm{MIU} / \mathrm{ml}$ IFN- $\alpha$-2b szemcseppet és/vagy subconjunctivalis injekciót, esetenként sebészi eltávolítással kombinálva. Ezzel a módszerrel 90\% feletti rezolúciót és átlagosan egy év után 5\% recidívagyakoriságot ért el [31].

$\mathrm{Az}$ IFN- $\alpha-2 b$ mellékhatásprofilja lényegesen kedvezőbb a többi lokális kemoterapeutikumhoz képest, hiszen csak enyhe szemirritációt, hyperaemiát vagy keratitis punctata superficialist okozhat, ami a kezelés elhagyását követően megszûnik. Hátránya viszont a kifejezetten magas ára. Az IFN- $\alpha$-2b-kezelés havi költsége az Amerikai Egyesült Államokban körülbelül 300 USD, ami hozzávetólegesen háromszorosa az 5-FU és kétszerese az MMC havi költségeinek [44].

\section{Brachytherapia}

Kenawy sebészi excisiót követően hat SCC-s páciensnél végzett fokális radioterápiát (brachytherapia). A conjunctiva sebészi excisio utáni gyógyulását követően, a szövettani diagnózis ismeretében, általános anesztéziában 15 mm-es ruténium-106-plakkot erősítettek a gyógyult kötőhártyára, a kimetszett tumorszövet helyére. A kezeléssel járó diszkomfortérzet enyhítése céljából terápiás kontaktlencsét illesztettek a szemre a kezelés idejére. A kezelés során a plakk 100 Gy dózis kezelést biztosított 24 óra alatt $1 \mathrm{~mm}$-es mélységben. A kezelés végén a plakkot helyi érzéstelenítésben távolították el. Öt évnél hosszabb utánkövetés során recidívára utaló jelet nem találtak [29].

Kearsley 123 OSSN-es páciensen végzett stroncium90-plakkal brachytherapiás kezelést a tumorszövet excisióját követő 48 órában, 30 Gy dózissal. Később tumorrecidíva csupán három esetben lépett fel. Lecuona 69 OSSN-es szemen végzett stroncium-90-plakkal (14 és 18 mm-es) frakcionált brachytherapiát az operatív eltávolítást követően. Külön érdekessége ezen mintának, hogy 47,5\%-uk HIV-vírussal fertőzött volt, akik esetében a tumorok agresszívabban viselkednek. A betegek négy héten át heti 15 Gy dózist kaptak, így összesen 60 Gy dózist. A páciensek 84\%-a még öt évvel a mütétet követően is recidívamentes volt [45].

A brachytherapiás kezelés mellékhatásaként ritkán scleralis fekély vagy szürke hályog alakuhat ki.

\section{Konzervatín kezelés}

Napjainkban paradigmaváltás figyelhető meg az OSSN kezelésében. A tradicionális adjuváns kezeléssel kombinált sebészi eltávolítás helyett egyre többen javasolják a tisztán konzervatív kezelést. A konzervatív kezelési mó- 
dok segítségével az egész szemfelszínt kezelhetjük és elkerülhetjük a kiterjedt tumoreltávolítással járó szövődményeket.

\section{MMC}

Frucht-Pery OSSN-ek kezelésére 14 napig alkalmazott naponta $4 \times 10,02 \%$-os MMC szemcseppet, illetve recidíva esetén 14 napig $4 \times 1 \quad 0,02 \%$-os vagy $0,04 \%$-os MMC szemcseppet, ez a kezelés azonban önmagában az esetek 35\%-ában nem volt sikeres és későbbi sebészi eltávolítást tett szükségessé. Hirst 26 páciensének adott $4 \times 10,04 \%$-os MMC szemcseppet három héten át, amellyel az esetek 92\%-ában teljes rezolúciót ért el [46]. Ballalai 23 beteg esetében, napi $4 \times 1$ 0,02\%-os MMC 28 napig való használata után teljes rezolúciót ért el, 24 hónapos utánkövetést követően pedig csak 4,3\%-nál lépett fel recidíva. Az MMC hosszú távú mellékhatásainak elkerülése céljából az adagolás ciklusokban javasolt. Wilson naponta $4 \times 1$ 0,04\%-os MMC szemcsepp segítségével három ciklust követően hét betegből hat esetében teljes rezolúciót ért el. Daniell 20 páciensnél ciklusokban adott napi $4 \times 1$ 0,02\%-os vagy $0,04 \%$-os MMC-t, amellyel átlagosan két ciklussal 90\%-ban ért el teljes rezolúciót, 13 hónap után pedig a páciensek $20 \%$-ánál talált recidívát. Mindezek alapján MMC szemcsepp egyedüli használatával átlagosan négy-öt hét alatt érhetô el rezolúció, recidíva pedig az esetek körülbelül 7\%-ában fordul elő [47].

\section{5-FU}

Midena hétből hét betegnél ért el teljes gyógyulást, négy héten át alkalmazott, naponta $4 \times 1$ 1\%-os 5-FU szemcsepp adásával [48]. Yeatts hét OSSN-es betegnek adott naponta $4 \times 1$ 1\%-os 5-FU szemcseppet kettönégy napon át, majd ezt 30-45 napos kezelési szünet követte (egy ciklus). Átlagosan 3,75 ciklust követően négy páciensnél teljes rezolúciót ért el. Három páciensnél lépett fel recidíva a kezdeti kezelés lezárását követôen, közülük kettőnél alakult ki teljes rezolúció ismételt 5-FU-kezelés indításával. Itt egy beteg a két 5-FU-kezelést követően MMC-kezelést kapott, amelynek köszönhetően teljes rezolúció alakult ki [49]. Al-Barrag 15 betegnek rendelt hatciklusnyi kezelést, egy ciklus során négy napig naponta $4 \times 1$ 1\%-os 5-FU-szemcsepp használatával, majd pedig 30 napos kezelési szünettel. 15 hónapos utánkövetés során recidíva egyetlen betegnél sem alakult ki. Parrozzani tanulmányában a 41 páciens négy héten át naponta $4 \times 1$ 1\%-os 5-FU-szemcseppet kapott. Négyhetes kezelést követően egy hónapig szüneteltették a lokális kemoterápiát, majd újabb 5-FU-ciklust kezdtek, amelyet a teljes rezolúcióig vagy a terápiás hatás megszűntéig folytattak. Átlagosan másfél ciklust követően a betegek 83\%-ánál alakult ki teljes rezolúció. Joag nemrégiben megjelent közleményében 44 pácienst kezeltek naponta $4 \times 1 \quad 1 \%$-os 5-FU-szemcseppel, amely során egy ciklusban a páciens egy hétig csepegtetett, majd három hétig nem használt 5-FU-t. Átlagosan négy ciklust követően az esetek 82\%-ában alakult ki teljes rezolúció, a recidívaráta egy év után $6 \%$, két év után pedig $15 \%$ volt [50].

\section{IFN- $\alpha-2 b$}

Karp 15 OSSN-es betegnél használt subconjunctivalis IFN- $\alpha$-2b-injekciót ( 3 MIU 0,5 ml-es oldalban). Az injekciókat heti rendszerességgel adták a teljes rezolúció eléréséig (átlagosan 1,4 hónap), amely 13 szemnél alakult ki. Ötvenöt hónapos utánkövetésnél egy esetben alakult ki recidíva. A szisztémás mellékhatások enyhítésére a szerző́k szükség szerint négyóránként 1000 mg paracetamol szedését javasolták [43]. Galor naponta $4 \times 1$ $\mathrm{l}$ vagy $3 \mathrm{MIU} / \mathrm{ml}$ IFN- $\alpha$-2b-szemcseppet adott a teljes gyógyulásig, illetve az azt követó egy hónapban. Ez a kezelés 33 szemnél hatásos volt, azonban két SCC-s esetében nem alakult ki teljes rezolúció és sebészi eltávolítás elvégzése vált szükségessé. A kétféle koncentráció között a vizsgálat során nem találtak különbséget a hatásosság tekintetében. Schechter 28 szemből 27-nél ért el gyógyulást, átlagosan két hónap után $4 \times 1 \mathrm{l}$ vagy $3 \mathrm{MIU} / \mathrm{ml}$ IFN- $\alpha$-2b-szemcsepp rendelésével [42].

\section{Esetbemutatások}

\section{Első beteg}

A 72 éves férfi beteg ambuláns rendelésünkön való jelentkezéskor bal szemén másfél hónapja egy fehér foltot látott. A páciens szemészeti anamnézise eseménytelen volt. Általános anamnézisében mind 2007-ben, mind 2014-ben háromszori szívinfarktus, majd háromszori coronariastent-beültetés, jobb-Tawara-szár-blokk, illetve 2006-ban colorectalis polip miatt végzett polipectomia szerepelt. A páciens jobb szemén a legjobb korrigált látóélesség (BCVA) 1,0 (+1,50 Dsph, $-1,00$ Dcyl $\left.80^{\circ}\right)$, a bal szemén pedig $0,7\left(+2,00 \mathrm{Dsph},-1,00 \mathrm{Dcyl} 115^{\circ}\right)$ volt. Réslámpás vizsgálat során a páciens bal szemén nasalisan az interpalpebralis régióban 9 és 12 h között leukoplakiás növedéket láttunk a limbalis régió és a szaruhártya felszínén. A tumor helyenként erezett volt $(2 / A$ ábra). Gonioszkópás vizsgálat során ép csarnokzugi képleteket láttunk. A szemfelszíni laesiót $3 \mathrm{~mm}$-es biztonsági széllel, a cornealis hámmal és a növedék alatti subconjunctivalis kötőszövettel együtt eltávolítottuk, az eltávolított területekkel szomszédos kötőhártyaszéleken pedig „double freeze-thaw” cryotherapiás kezelést végeztünk. A mútétet követően a teljes hámosodásig naponta $5 \times 1$ Tobradex szemcseppet (tobramycin és dexamethason) rendeltünk az operált szembe. A szövettani vizsgálat $(2 / D$ ábra $)$ súlyos fokú hámdysplasiát, intakt bazális membránt és épben történt kimetszést mutatott, így conjunctivalis intraepithelialis neoplasiát diagnosztizáltunk (TisN0M0). A mútét után 10 hónappal a páciens operált szemének BCVA-ja 1,0 (korrekció: +1,50 Dsph, $-0,50$ Dcyl $\left.140^{\circ}\right)$ volt, recidívára utaló jelet pedig nem találtunk (2/B és $2 / C$ ábra). 

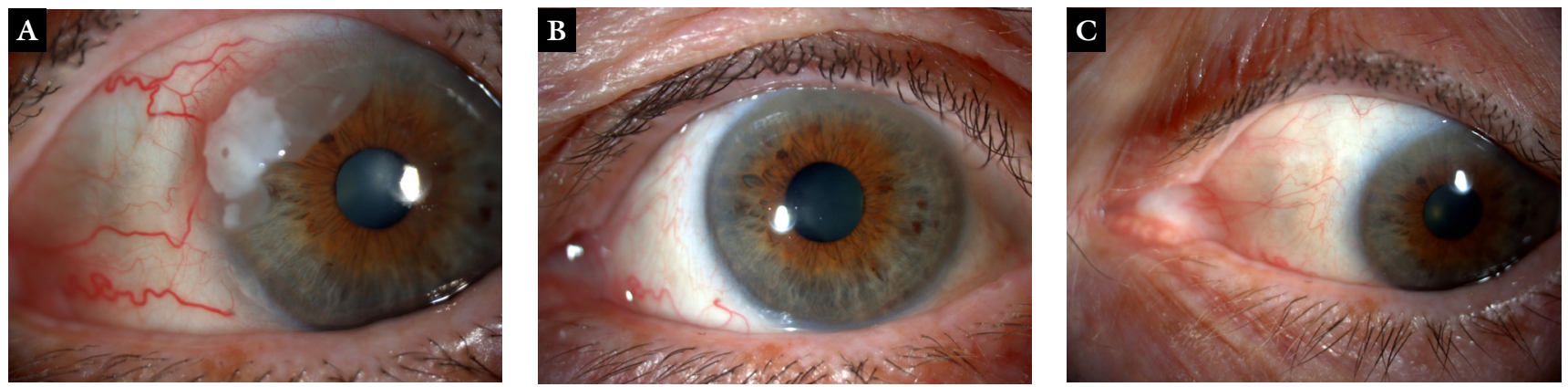

2/A-C ábra Első beteg OSSN-es szeméről készült fotón a szaruhártya temporalis felső kvadránsában a limbalis régiót is borító terime látható (szövettan: conjunc tivalis intraepithelialis neoplasia) az első megjelenéskor (A). 10 hónappal a mútét után lokális recidíva nem látható a réslámpás felvételen (B, C)

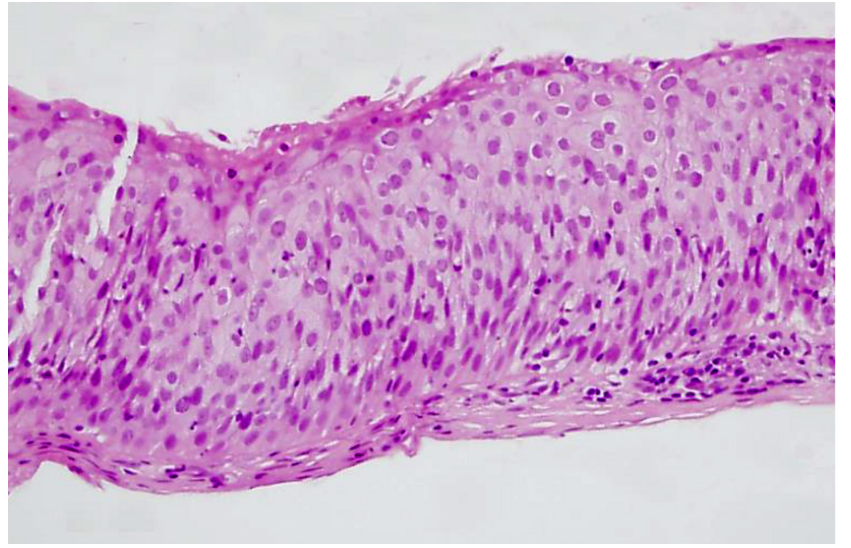

2/D ábra

Első beteg: Hematoxilin-eozin festéssel (eredeti nagyítás 200-szoros) az eltávolított terime szövettani vizsgálatakor a felszíni parakeratosis mellett, rendezetlen hámstruktúrát, pleomorphiát, illetve a bazális réteg felett, a hám teljes vastagságában mitózisokat láttunk. A megvastagodott hámban némi kiérés is ábrázolódott, a tumorszövet a bazális membránt nem törte át (conjunctivalis intraepithelialis neoplasia)

\section{Második beteg}

A 70 éves férfi beteg három hete kezdődő bal oldali szemvörösséggel és -könnyezéssel jelentkezett klinikánk ambuláns rendelésén. Szemészeti anamnézise eseménytelen volt, általános anamnézisében epehólyag-eltávolítás és gyermekkora óta fennálló hallássérültség szerepelt. A páciens BCVA-ja a jobb szemen 0,8 (-1,50 Dsph), a bal szemen pedig 2 mou volt. Biomikroszkópos vizsgálattal a bal szem felszínének temporalis és alsó részén, 3 és 7 óra között a kötőhártyát és a szaruhártyát is érintő, erezettséget mutató tumorszövetet láttunk ( $3 / A$ és $3 / B$ ábra). Gonioszkópiás vizsgálat során a csarnokzug ép volt. Az érintett szemen „double freeze-thaw” cryotherapiával kombinált sebészi eltávolítást végeztünk 3 mm-es biztonsági széllel. A nagy felületen eltávolított cornealis hám miatt, a reepithelisatio elősegítésének céljából, amnionpatchet rögzítettünk episcleralisan. Posztoperatív lokális kezelésként, a teljes hámosodásig, naponta $5 \times 1$ Tobradex szemcseppet (tobramycin és dexamethason) rendeltünk és terápiás kontaktlencsét illesztettünk az operált szemre. A szövettani vizsgálat (3/E ábra) középsúlyos hámdysplasiát, intakt bazális membránt és épben történt kimetszést mutatott, így conjunctivalis intraepithelialis neoplasiát diagnosztizáltunk (TisN0M0). A mútét után 12 hónappal a páciens operált szemének BCVA-ja 0,3 (korrekció: -1,00 Dsph, $-2,00$ Dcyl $80^{\circ}$ ) volt, amit a parancentrálisan látható cornealis dellen magyarázott, recidívára utaló jelet pedig nem láttunk (3/C és $3 / D$ ábra).

\section{Harmadik beteg}

Az 50 éves nőbeteg három hónapja jobb szemen lévő növedékkel jelentkezett első alkalommal klinikánk ambuláns rendelésén. A páciens szemészeti anamnézise eseménytelen volt. Általános anamnézisében egy éve ismert magas vérnyomás és 24 éve inzulinnal kezelt cukorbetegség szerepelt. A beteg egy éve veseelégtelen volt és vesetranszplantációra várt. A páciens BCVA-ja a jobb szemen korrekció nélkül 1,0 , a bal szemen enyhe hypermetrop korrekcióval (+0,75 Dsph) 1,0 volt. Réslámpás vizsgálattal a jobb szemének felszíni temporalis részén, az interpalpebralis régióban zselatinszerü kötőhártya-elváltozást láttunk ( $4 / \mathrm{A}$ ábra), amely sem a szaruhártyára, sem pedig a limbusra nem terjedt rá, azonban az alsó szemhéj tarsalis oldalán megtalálható volt. Gonioszkópiás vizsgálat ép csarnokzugi képleteket mutatott. A páciens jobb szemén $3 \mathrm{~mm}$-es biztonsági széllel való operatív eltávolítást és „double freeze-thaw” technikával cryotherapiát végeztünk. A nagy területen elvégzett kötőhártya-eltávolítás miatt kötőhártya pótlása céljából graftként amnionmembránt alkalmaztunk, valamint Illig-kagylót helyeztünk a szemrésbe a synblepharon kialakulásának megelőzésére, majd a teljes hámosodásig naponta $5 \times 1$ Tobradex szemcseppet (tobramycin és dexamethason) rendeltünk.

A szövettani vizsgálat invazív SCC-t igazolt $(4 / D$ ábra), a kimetszés nem az épben történt. A teljes hámosodást követően két ciklusban (egy ciklus során egy hét csepegtetés, majd egy hét terápiamentes időszak) naponta $5 \times 10,02 \%$-os Mitomycin C szemcseppet alkalmaztunk. Az Illig-kagyló használata ellenére, a korábbi mútéti területnek megfelelően, symblepharon alakult ki, tumorrecidíva azonban klinikailag nem volt látható. Tizenkét hónapos utánkövetés során recidívára utaló jel 

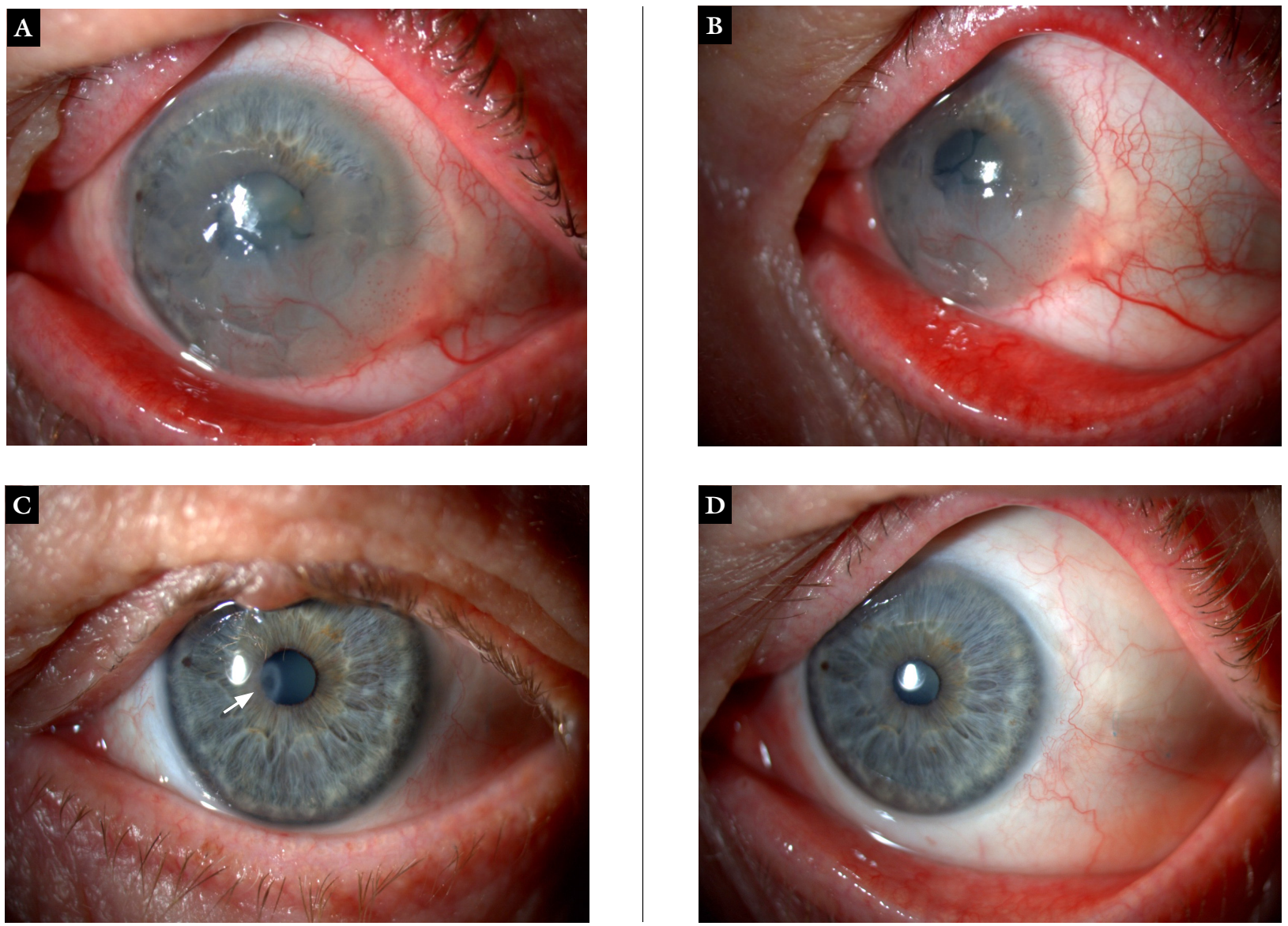

3/A-D ábra $\mid$ Második beteg OSSN-es szeméról készült fotó az első megjelenéskor (A, B): csaknem a teljes szaruhártyahámot beszűrő lapos terime látható, amely temporalisan a paralimbalis conjunctivát is borítja (szövettan: conjunctivalis intraepithelialis neoplasia). Egy évvel a mútétet követően (C, D) paracentrális dellen ábrázolódik (nyíl, C), azonban lokális recidíva nem igazolható

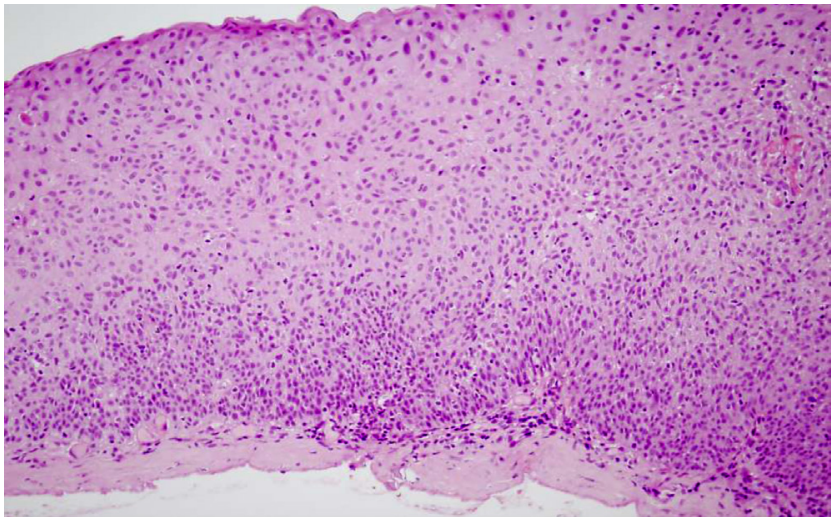

$3 /$ ábra

Második beteg: Hematoxolin-eozin festést követően (eredet nagyítás 200-szoros) az eltávolított terimében kiszélesedett, megtartott polarizáltságú, kissé rendezetlen struktúrájú epithelréteg volt látható. A bazális réteg felett a hám alsó kétharmadában mitózisok és helyenként dyskeratosis ábrázolódtak. A hám felszínes egyharmadában a kiérés egyértelmű volt, a tumorszövet a bazális membránt nem törte át (conjunctivalis intraepithe lialis neoplasia)

változatlanul nem mutatkozott (4/B és 4/C ábra), illetve regionális lymphadenopathia, távoli metasztázis nem volt kimutatható (T2N0M0). Ekkor az operált szem látóélessége korrekció nélkül 1,0 volt.

\section{Negyedik beteg}

A 71 éves férfi beteg ambuláns rendelésünkön való jelentkezésekor jobb szemén két hete növekedő elváltozást látott. A beteg szemészeti anamnézise eseménytelen volt. Általános anamnézisében 1972-ben oesophagealis leiomyoma-, 1976-ban epehólyag- és 1977-ben vakbéleltávolítás szerepelt. A páciens jobb szemén a korrigálatlan látóélesség 0,9 , a bal szemén pedig 1,0 volt. Réslámpás vizsgálat során a beteg jobb szemfelszínének nasalis területén az interpalpebralis régióban 1 és 5 h között, limbusból kiinduló papillomatosus növedéket láttunk $(5 / A$ ábra). Gonioszkópiás vizsgálat során ép csarnokzugot találtunk. A szemfelszíni tumorszövetet $3 \mathrm{~mm}$-es biztonsági széllel együtt eltávolítottuk. A mútétet követően a teljes reepithelisatióig naponta $5 \times 1$ Tobradex cseppet (tobramycin és dexamethason) rendeltünk a mútött szembe. A szövettani vizsgálat invazív SCC-t mutatott $(5 / \mathrm{D}$ ábra), a tumorszövet eltávolítása pedig nem az épben történt. A beteg a teljes hámosodást követően két ciklusban naponta $5 \times 10,02 \%$-os Mitomycin C szemcseppet kapott. Kétéves utánkövetés során tumorrecidíva nem jelentkezett (5/B és 5/C ábra), regionális lymphadenopathia vagy távoli metasztázis pedig nem volt igazolható (T2N0M0). A páciens BCVA-ja az érintett szemen ekkor 1,0 (korrekció: +0,50 Dsph, -0,50 Dcyl 60 ) volt. 

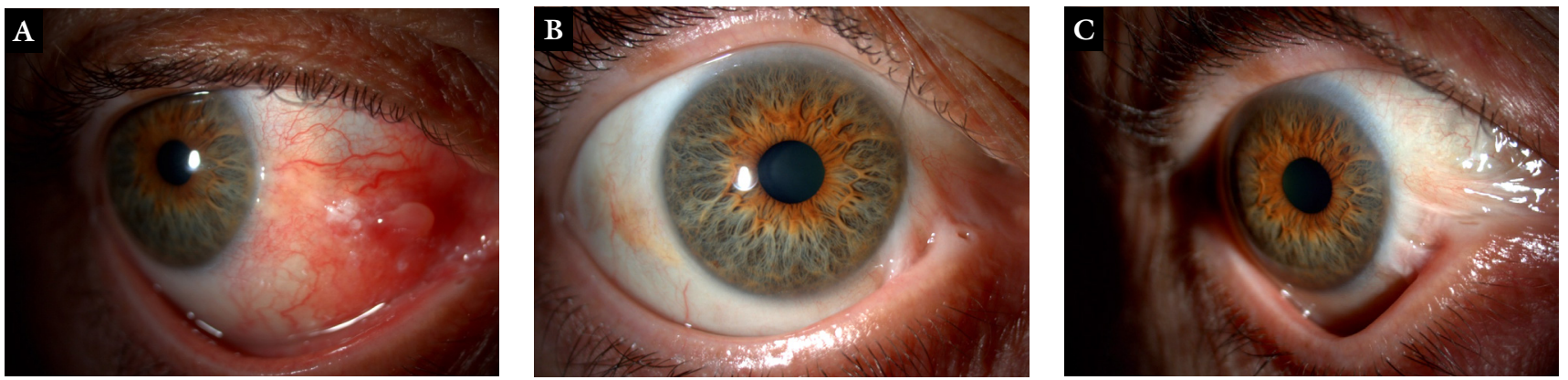

4/A-C ábra $\mid$ Harmadik beteg OSSN-es szeméről készült fotó az első megjelenéskor (A): a belső zugban a bulbaris és az alsó tarsalis conjunctiva területében elő emelkedő terime, tágult erekkel körbevéve látható (szövettan: invazív laphámcarcinoma). Egy évvel a mútétet követően nasalisan symblepharon figyelhető meg, azonban lokális recidíva nem igazolható $(\mathrm{B}, \mathrm{C})$

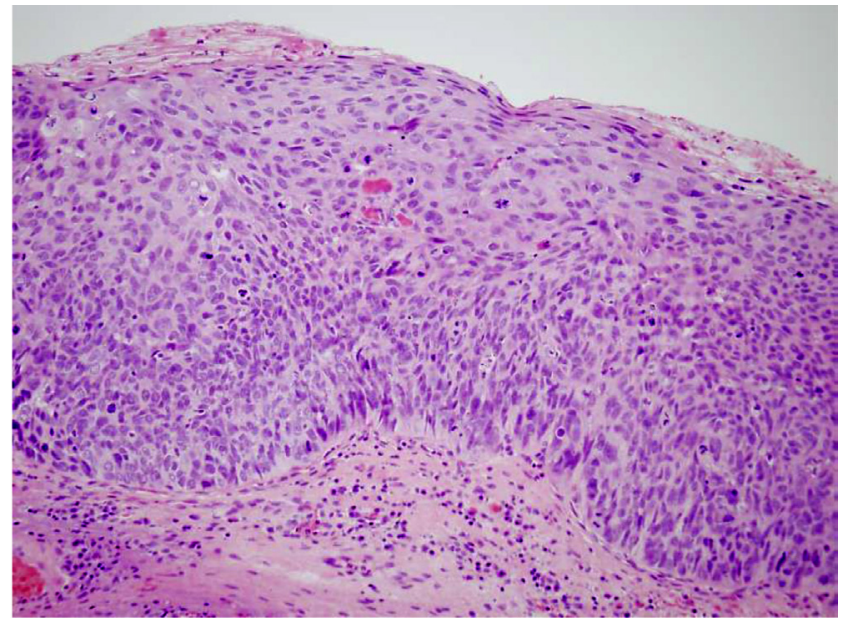

4/D ábra

Harmadik beteg: Hematoxilin-eozin festéssel (eredeti nagyítás 200-szoros) az eltávolított terime vizsgálatakor megvastagodott, rendezetlen, helyenként parakeratoticus felszínú epithelréteg volt látható. Mitózisok, dyskeratoticus tumorsejtek a hám teljes szélességében megfigyelhetőek voltak. A kötőhártya alatti kötőszövetben néhol lymphoplasmocytás beszürődés volt látható. Jelen felvételen az a terület, ahol a tumorszövet a bazális membránt áttörte, nem ábrázolódik (invazív laphámcarcinoma)

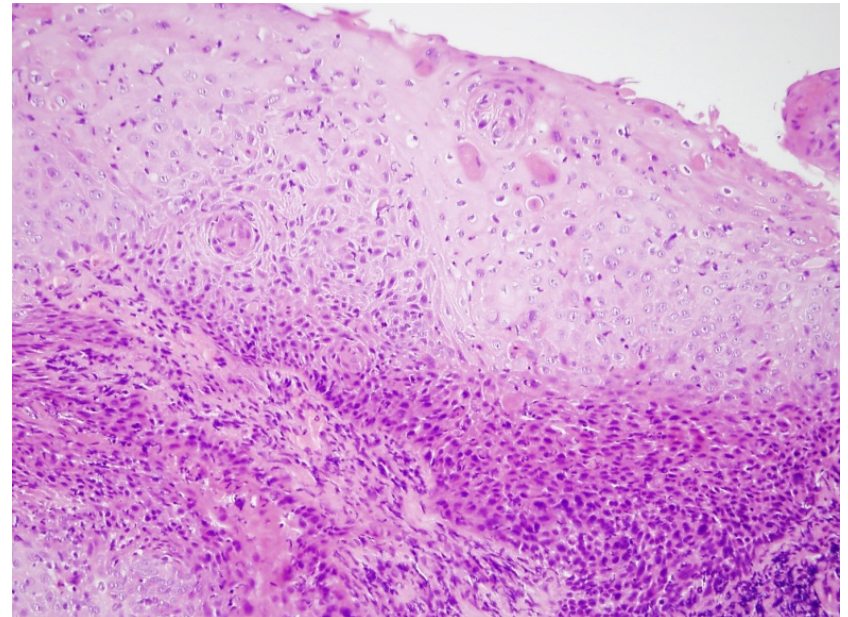

5/D ábra

Negyedik beteg: Hematoxilin-eozin festéssel (eredeti nagyítás 200-szoros) az eltávolított terime szövettani vizsgálatakor több nucleolusú, vesicularis maggal rendelkező daganatsejtek voltak megfigyelhetőek. Kifejezett pleomorphia, helyenként dyskeratoticus tumorsejtek és lobsejtes beszúrődés is láthatóak voltak A daganat a bazális membránt áttörte (invazív laphámcarcinoma)
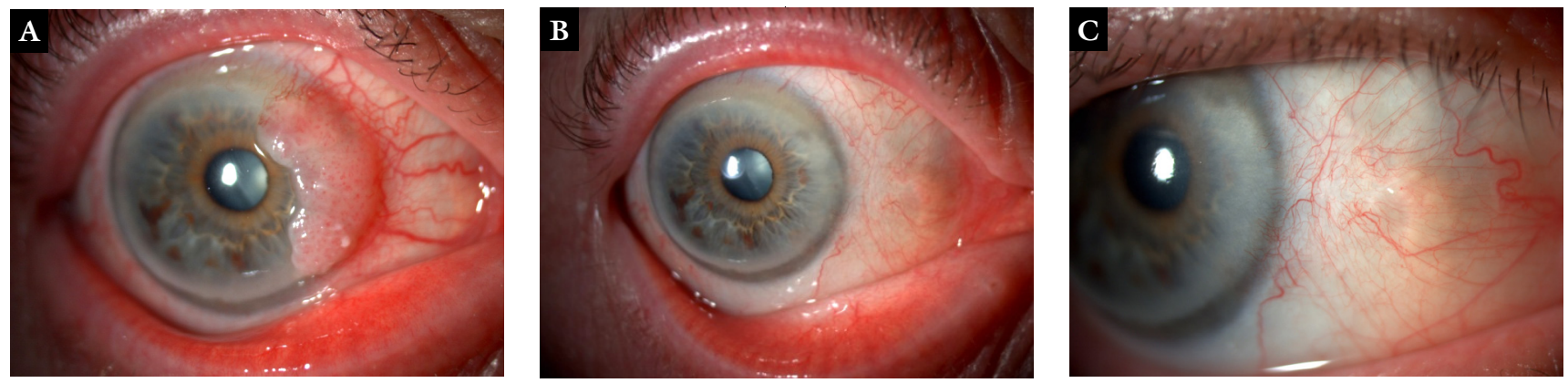

5/A-C ábra $\mid$ Negyedik beteg OSSN-es szeméről készült fotó az első megjelenéskor (A): nasalisan a limbus és a szaruhártya felett előemelkedő terime látható, amelyhez tágult erek húzódnak (szövettan: invazív laphámcarcinoma). Két évvel a mútétet követően lokális recidíva nem volt igazolható (B, C)

\section{Következtetések}

Az OSSN kezelésére betegbiztonsági és költséghatékonysági szempontokból ajánlott kezelési mód a sebészi excisio cryotherapiával való kombinálása, illetve annak az intra- vagy posztoperatív időszakban adjuváns lokális kemoterapeutikummal való kiegészítése, különösen abban az esetben, ha a tumorszövet kimetszése nem az épben történt. Rendkívül fontos még ezen páciensek élethosszig való évenkénti szemészeti vizsgálata, az esetleges OSSN-recidívák időben történő felismerése céljából. 
Anyagi támogatás: Készült „Az orvos-, egészségtudományi- és gyógyszerészképzés tudományos múhelyeinek fejlesztése" címü projekt támogatásával (azonosítószám: EFOP-3.6.3-VEKOP-16-2017-00009; Dr. Tóth Gábor). A támogatónak nem volt szerepe a kézirat megtervezésében vagy megírásában.

Szerzői munkamegosztás: T. G., S. G. L., Gy. A., T. J., B. S., N. Z. Zs., Sz. N.: Irodalomgyüjtés. T. G., B. S., N. Z. Zs., Sz. N.: A kézirat megszövegezése és javítása. A cikk végleges változatát valamennyi szerző elolvasta és jóváhagyta.

Érdekeltségek: A szerzőknek nincsenek érdekeltségeik.

\section{Köszönetnyilvánítás}

Köszönjük Széles Évának a fotográfiai anyagok elkészítését és szerkesztését.

\section{Irodalom}

[1] Lee GA, Hirst LW. Incidence of ocular surface epithelial dysplasia in metropolitan Brisbane. A 10-year survey. Arch Ophthalmol. 1992; 110: 525-527.

[2] Basti S, Macsai MS. Ocular surface squamous neoplasia: a review. Cornea 2003; 22: 687-704.

[3] Lugossy G. Precancerous conditions of the bulbar conjunctiva. Am J Ophthalmol. 1956; 42: 107-112.

[4] Lee GA, Hirst LW. Ocular surface squamous neoplasia. Surv Ophthalmol. 1995; 39: 429-450.

[5] Templeton AC. Tumors of the eye and adnexa in Africans of Uganda. Cancer 1967; 20: 1689-1698.

[6] Sun EC, Fears TR, Goedert JJ. Epidemiology of squamous cell conjunctival cancer. Cancer Epidemiol Biomarkers Prev. 1997; 6: 73-77.

[7] Yang J, Foster CS. Squamous cell carcinoma of the conjunctiva. Int Ophthalmol Clin. 1997; 37: 73-85.

[8] Gichuhi S, Sagoo MS, Weiss HA, et al. Epidemiology of ocular surface squamous neoplasia in Africa. Trop Med Int Health 2013; 18: 1424-1443.

[9] Hertle RW, Durso F, Metzler JP, et al. Epibulbar squamous cell carcinomas in brothers with xeroderma pigmentosa. J Pediatr Ophthalmol Strabismus 1991; 28: 350-353.

[10] Kiire CA, Dhillon B. The aetiology and associations of conjunctival intraepithelial neoplasia. Br J Ophthalmol. 2006; 90: 109113.

[11] Pater MM, Dunne J, Hogan G, et al. Human papillomavirus types 16 and 18 sequences in early cervical neoplasia. Virology 1986; 155: 13-18.

[12] McDonnell JM, Mayr AJ, Martin WJ. DNA of human papillomavirus type 16 in dysplastic and malignant lesions of the conjunctiva and cornea. N Engl J Med. 1989; 320: 1442-1446.

[13] McDonnell JM, McDonnell PJ, Sun YY. Human papillomavirus DNA in tissues and ocular surface swabs of patients with conjunctival epithelial neoplasia. Invest Ophthalmol Vis Sci. 1992; 33: 184-189.

[14] Waddell K, Magyezi J, Bousarghin L, et al. Antibodies against human papillomavirus type 16 (HPV-16) and conjunctival squamous cell neoplasia in Uganda. Br J Cancer 2003; 88: 20022003.

[15] Ateenyi-Agaba C. Conjunctival squamous-cell carcinoma associated with HIV infection in Kampala, Uganda. Lancet 1995; 345: 695-696.
[16] Newton R. A review of the aetiology of squamous cell carcinoma of the conjunctiva. Br J Cancer 1996; 74: 1511-1513.

[17] Waddell KM, Lewallen S, Lucas SB, et al. Carcinoma of the conjunctiva and HIV infection in Uganda and Malawi. Br J Ophthalmol. 1996; 80: 503-508.

[18] Karp CL, Scott IU, Chang TS, et al. Conjunctival intraepithelial neoplasia. A possible marker for human immunodeficiency virus infection? Arch Ophthalmol. 1996; 114: 257-261.

[19] Wilson FM 2nd. Rose bengal staining of epibulbar squamous neoplasms. Ophthalmic Surg. 1976; 7: 21-23.

[20] McKelvie PA, Daniell M, McNab A, et al. Squamous cell carcinoma of the conjunctiva: a series of 26 cases. $\mathrm{Br} J$ Ophthalmol. 2002; 86: 168-173.

[21] De Potter P, Shields CL, Shields JA, et al. Clinical predictive factors for development of recurrence and metastasis in conjunctival melanoma: a review of 68 cases. Br J Ophthalmol. 1993; 77 : 624-630.

[22] Nelson KD, McSoley JJ. Clinical findings and management of conjunctival intraepithelial neoplasia. Optometry 2011; 82: 1521.

[23] Tóth J. Ophthalmic pathology. In: Schaff Z. (ed.) Pathology. [Szempatológia. In: Schaff Z. (szerk.) Patológia.] Medicina Könyvkiadó, Budapest, 2004; pp. 1292-1315. [Hungarian]

[24] Grossniklaus HE, Green WR, Luckenbach M, et al. Conjunctival lesions in adults. A clinical and histopathologic review. Cornea 1987; 6: 78-116.

[25] Yeatts RP, Ford JG, Stanton CA, et al. Topical 5-fluorouracil in treating epithelial neoplasia of the conjunctiva and cornea. Ophthalmology 1995; 102: 1338-1344.

[26] Tole DM, McKelvie PA, Daniell M. Reliability of impression cytology for the diagnosis of ocular surface squamous neoplasia employing the Biopore membrane. Br J Ophthalmol. 2001; 85: 154-158.

[27] Nolan GR, Hirst LW, Wright RG, et al. Application of impression cytology to the diagnosis of conjunctival neoplasms. Diagn Cytopathol. 1994; 11: 246-249.

[28] Edge SB, Byrd DR, Compton CC, et al. Carcinoma of the conjunctiva. In: Edge SE, Byrd DR, Carducci MA, et al. (eds.) AJCC cancer staging manual. 7th ed. Springer, New York, 2009; pp. 531-537.

[29] Kenawy N, Garrick A, Heimann H, et al. Conjunctival squamous cell neoplasia: the Liverpool Ocular Oncology Centre experience. Graefes Arch Clin Exp Ophthalmol. 2015; 253: 143-150.

[30] Sarici AM, Arvas S, Pazarli H. Combined excision, cryotherapy, and intraoperative mitomycin C (EXCRIM) for localized intraepithelial and squamous cell carcinoma of the conjunctiva. Graefes Arch Clin Exp Ophthalmol. 2013; 251: 2201-2204.

[31] Shields CL, Kaliki S, Kim HJ, et al. Interferon for ocular surface squamous neoplasia in 81 cases: outcomes based on the American Joint Committee on Cancer classification. Cornea 2013; 32: 248-256.

[32] Shields JA, Shields CL, De Potter P. Surgical management of conjunctival tumors. The 1994 Lynn B. McMahan Lecture. Arch Ophthalmol. 1997; 115: 808-815.

[33] Tunc M, Char DH, Crawford B, et al. Intraepithelial and invasive squamous cell carcinoma of the conjunctiva: analysis of 60 cases. Br J Ophthalmol. 1999; 83: 98-103.

[34] Tabin G, Levin S, Snibson G, et al. Late recurrences and the necessity for long-term follow-up in corneal and conjunctival intraepithelial neoplasia. Ophthalmology 1997; 104: 485-492.

[35] Khokhar S, Soni A, Singh Sethi H, et al. Combined surgery, cryotherapy, and mitomycin- $\mathrm{C}$ for recurrent ocular surface squamous neoplasia. Cornea 2002; 21: 189-191.

[36] Siganos CS, Kozobolis VP, Christodoulakis EV. The intraoperative use of mitomycin-C in excision of ocular surface neoplasia with or without limbal autograft transplantation. Cornea 2002; 21: 12-16. 
[37] Módis L, Tóth E, Berta A. Surgical treatment of ocular surface diseases. [A szemfelszín betegségeinek sebészi kezelése.] Orv Hetil. 2009; 150: 1599-1606. [Hungarian]

[38] Bucher F, Parthasarathy A, Bergua A, et al. Topical ranibizumab inhibits inflammatory corneal hem- and lymphangiogenesis. Acta Ophthalmol. 2014; 92: 143-148

[39] Asena L, Dursun Altinors D. Topical bevacizumab for the treatment of ocular surface squamous neoplasia. J Ocul Pharmacol Ther. $2015 ; 31: 487-490$.

[40] Gupta A, Muecke J. Treatment of ocular surface squamous neoplasia with Mitomycin C. Br J Ophthalmol. 2010; 94: 555-558.

[41] Bahrami B, Greenwell T, Muecke JS. Long-term outcomes after adjunctive topical 5 -flurouracil or mitomycin $\mathrm{C}$ for the treatment of surgically excised, localized ocular surface squamous neoplasia. Clin Exp Ophthalmol. 2014; 42: 317-322.

[42] Galor A, Karp CL, Chhabra S, et al. Topical interferon alpha 2b eye-drops for treatment of ocular surface squamous neoplasia: a dose comparison study. Br J Ophthalmol. 2010; 94: 551-554.

[43] Karp CL, Galor A, Chhabra S, et al. Subconjunctival/perilesional recombinant interferon $\alpha 2 \mathrm{~b}$ for ocular surface squamous neoplasia: a 10-year review. Ophthalmology 2010; 117: 2241-2246.

[44] Esquenazi S, Fry CL, Holley E. Treatment of biopsy proved conjunctival intraepithelial neoplasia with topical interferon alfa- $2 \mathrm{~b}$. Br J Ophthalmol. 2005; 89: 1221 .
[45] Lecuona K, Stannard C, Hart G, et al. The treatment of carcinoma in situ and squamous cell carcinoma of the conjunctiva with fractionated strontium-90 radiation in a population with a high prevalence of HIV. Br J Ophthalmol. 2015; 99: 11581161.

[46] Hirst LW. Randomized controlled trial of topical mitomycin C for ocular surface squamous neoplasia: early resolution. Ophthalmology 2007; 114: 976-982.

[47] Nanji AA, Sayyad FE, Karp CL. Topical chemotherapy for ocular surface squamous neoplasia. Curr Opin Ophthalmol. 2013; 24: 336-342.

[48] Midena E, Angeli CD, Valenti M, et al. Treatment of conjunctival squamous cell carcinoma with topical 5 -fluorouracil. $\mathrm{Br} \mathrm{J}$ Ophthalmol. 2000; 84: 268-272.

[49] Yeatts RP, Engelbrecht NE, Curry CD, et al. 5-fluorouracil for the treatment of intraepithelial neoplasia of the conjunctiva and cornea. Ophthalmology 2000; 107: 2190-2195.

[50] Parrozzani R, Frizziero L, Trainiti S, et al. Topical 1\% 5-fluoruracil as a sole treatment of corneoconjunctival ocular surface squamous neoplasia: long-term study. Br J Ophthalmol. 2017; 101: 1094-1099.

(Tóth Gábor dr.,

Budapest, Üllői út 26., 1085 e-mail: gabortothgabor@gmail.com)

\section{NOTA \\ Új fejlesztés az egészségügyben dolgozók, tanulók részére!}

A magyar nyelvứ szakirodalmi keresőszolgáltatás

\section{MI a NOTA? \\ Napivizit Orvosi Tudástár Alkalmazás}

Mit tud a NOTA portál?

Megkönnyíti a magyar nyelvű szakirodalmi források keresését.

Eszköztöl függetlenül, akár okostelefonról, a betegágy mellett állva is használható.

\section{Miben kereshet a NOTA-val?}

Az Akadémiai Kiadó folyóirataiban: Orvosi Hetilap, Magyar Sebészet, Mentálhigiéné és Pszichoszomatika.

\section{Más kiadók magyar nyelvü} szakfolyóirataiban: pl. Lege Artis Medicinae, Hypertonia és Nephrologia, Ideggyógyászati Szemle.

A hatályos szakmai irányelvekben.

Magyar nyelvű kérdésekre adott angol nyelvű találatokban, a PubMeden.

\section{nota.hu}

Amennyiben további információra lenne szüksége, keressen minket elérhetőségeinken:

journals@akademiai.hu /hirdetes@akademiai.hu

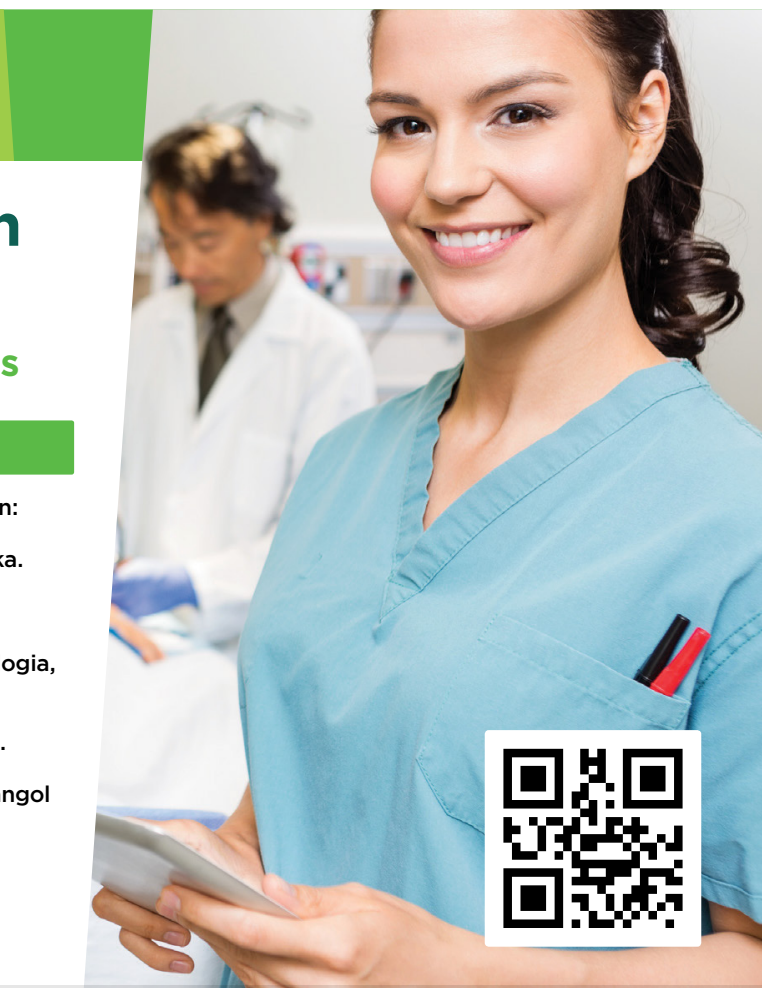

\section{Akadémiai Kiadó}

A Wolters Kluwer Csoport tagja

1117 Budapest, Prielle Kornélia u. 21-35. / Telefon: (1) 464-8246 www.akademiai.hu / www.akademiai.com

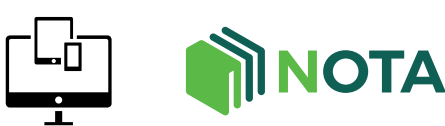

AKADÉMIAI KIADÓ 